\title{
Modelling of Permanent Deformation on Flexible Pavement Using Accelerated Pavement Testing
}

\author{
Khan Shahbaz ${ }^{1}$, Tiwari, Devesh ${ }^{2}$, Nagabhushana M.N ${ }^{2}$, Jain P.K ${ }^{3}$ \\ 1 .Academy of Scientific and Innovative Research, CSIR-CRRI, India., \\ 2 .Principal Scientist, Pavement Evaluation Division, CSIR-Central Road Research Institute, India. \\ 2 .Principal Scientist and Nodal Officer APTF Program, Flexible Pavement Division, CSIR-Central Road \\ Research Institute, India \\ 3.Chief Scientist and Head, Flexible Pavement Division, CSIR-Central Road Research Institute, India.
}

\begin{abstract}
The two major distresses encountered on flexible pavement under Indian conditions are fracture (cracking) and longitudinal permanent deformation (rutting) which affects the serviceability of pavement. Accelerated Pavement Testing Facility (APTF) is a tool which is a vital link for testing and measuring full-scale field behaviour of cracking and rutting of pavement at in-situ conditions. Recently, CSIR-Central Road Research Institute (CRRI) in India has procured a linear Heavy Vehicle Simulator (HVS) type of APTF which is presently being used for finding out the cracking and rutting behaviour of a flexible pavement consisting Dense Bituminous Concrete (DBC) as wearing course and Dense Bituminous Macadam (DBM) as binder course apart from the conventional granular layers above sub-grade.

The present paper deals with the development of a statistical model and its approach for pavement rutting under numerous passes (bi-directional) for the layer specifications which are (i) $40 \mathrm{~mm} D B C$ (ii) 120 mm DBM (iii) $250 \mathrm{~mm}$ Wet Mix Macadam (WMM) and (iv) $300 \mathrm{~mm}$ Granular Sub-base (GSB) above the Subgrade, which is an Indian Specification widely used for 30 Million Standard Axles (MSA) at 5\% CBR. The statistical model has been developed by observing / recording pavement surface profile using Laser Profilometer (off board) for every 5,000 passes upto 50,000 passes, thereafter at every 10,000 passes upto 175,000 passes and then at every 25,000 passes upto 275,000 passes. The details of methodology adopted, load applied, temperature and material properties have also been given in the paper.
\end{abstract}

Keywords: Flexible pavement, Rutting, Accelerated Pavement Testing Facility,Modelling,Profilometer.

\section{Introduction:}

In Indian conditions, pavements are subjected to extremely varying seasons from hot to cold, therefore, possibilities of rutting and fatigue failures both can take place in flexible pavement. A rut is characterised by longitudinal surface depression within the wheel path and may have associated transverse displacement, thereby reducing serviceability and safety of a flexible pavement. Rutting can be the result of permanent reduction in volume (consolidation/traffic densification), permanent movement of the material at constant volume (plastic deformation/shear), or a combination of the both the two [1]. Bituminous concrete (BC) specification is a time, temperature and stress dependent material, which, when subjected to repeated loading exhibits visco-elastic or plastic responses. The visco-elastic properties are modelled by modulus of elasticity and Poisson's ratio since they do not contribute to permanent deformation. Plastic properties contribute to permanent deformation, which is cumulative under repeated loading. There are several factors that influence rutting. Variables such as vehicle speed, time and contact pressure are directly represented in the creep rate model, while temperature, asphalt/bitumen mixture characteristics and construction quality are represented as values of the constants. Shear resistance properties of materials, especially bituminous, need to be properly addressed for limiting the rutting. While pavement structural design practices mainly focuses on protecting the subgrade by excessive vertical strain, whereas, shear resistance of the bituminous layers has been left to mixture designers. Adequacy of shear resistance in bituminous mixture is commonly assessed with empirical methods, such as Marshall Stability. There is a conscious effort to shift towards the use of fundamental performance-related test methods. Two procedures have been used to limit rutting; one to limit the vertical compressive strain on top of the subgrade, the other to limit the total accumulated permanent deformation on the pavement surface which is based on the properties of each individual layer. In the process, the number of load repetitions $\left(\mathrm{N}_{\mathrm{r}}\right)$ to limit rutting is related to the vertical compressive strain $\left(\varepsilon_{z}\right)$ on top of the subgrade (equation 1).

$$
\mathrm{N}_{\mathrm{r}}=\mathrm{f}_{1} \times\left(\frac{1}{\varepsilon_{\mathrm{z}}}\right)^{\mathrm{f}_{2}} .
$$

Several agencies have defined different values for constants $\mathrm{f} 1$ and $\mathrm{f} 2$. As per the earlier research in India, the rutting model is defined from large number of data obtained from pavements subjected to rutting failure. Setting the allowable rut depth as $20 \mathrm{~mm}$ [2], rutting equation has been presented as equation 2. 


$$
\mathrm{N}_{\mathrm{r}}=4.1656 \times 10^{-8} \times\left(\frac{1}{\varepsilon_{\mathrm{z}}}\right)^{4.5337}
$$

$\mathrm{N}_{\mathrm{r}}=$ No of Load Repetition in Rutting Failure

$\varepsilon_{\mathrm{Z}}=$ the compressive strain on the top of subgrade.

To study the effect of rutting failure on flexible pavement, Accelerated Pavement Testing Facility (APTF) is the most appropriate tool and also herein used.

\section{Accelerated Pavement Testing for Rutting Evaluation}

Accelerated Pavement Testing (APT) constitutes a vital link between the Pavement Engineering (P-E) tools for laboratory evaluation of pavement materials and to understand the full-scale in-situ field behaviour of these materials under a dynamic load within a pavement structure, as shown in figure 1. It supports most of the current pavement design methods and forms the basis for developing various theories about pavement behaviour and For this reason, APT has been regarded as a tool which provides pavement engineers the knowledge of understanding the behaviour of pavement materials and structures in a better way under varying traffic loading and known environmental conditions. APT aims to evaluate pavement sections under a range of loading and environmental conditions to improve the knowledge on the performance of the pavement layers and structure under a full range of field operational conditions.

Development of rutting is caused by a combination of densification and shear-related deformation with an increasing number of load applications which may occur in any layer of a pavement structure [3]. Hence, the pavement structural designs, bituminous mix designs, and pavement construction aims at minimising permanent deformation. As a result, pavement structures are composed of number of layers possessing required performance properties. These layers attenuate load-induced stresses and limit subgrade stress and deflection. It must, therefore, be ensured that the flexural and shear resistance of the structural layers are good enough to sustain these high stress states.

\subsection{APT Facility}

In the present case, evaluation of a flexible pavement has been done using linear Heavy Vehicle Simulator (HVS) type of APTF. The facility is in operation in Central Road Research Institute (CRRI) premises which is one of the premier laboratories of Council of Scientific and Industrial Research (CSIR) in India, as shown in Photo 1 and the salient features of HVS are presented in Table 1.

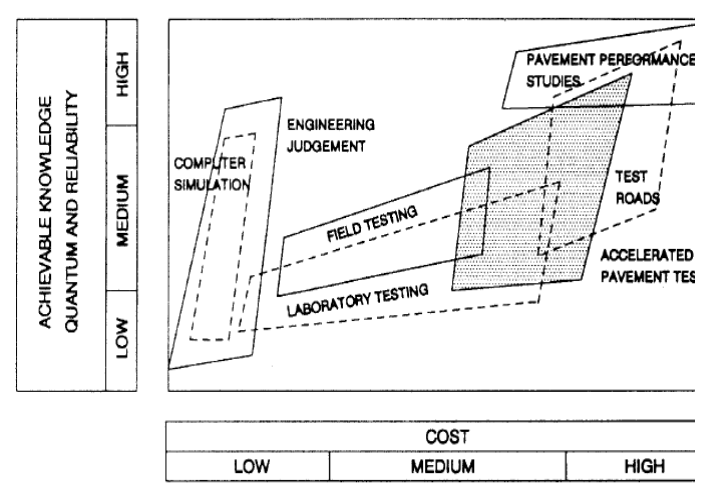

Fig.1 Interrelationship Between P-E Tools [4]

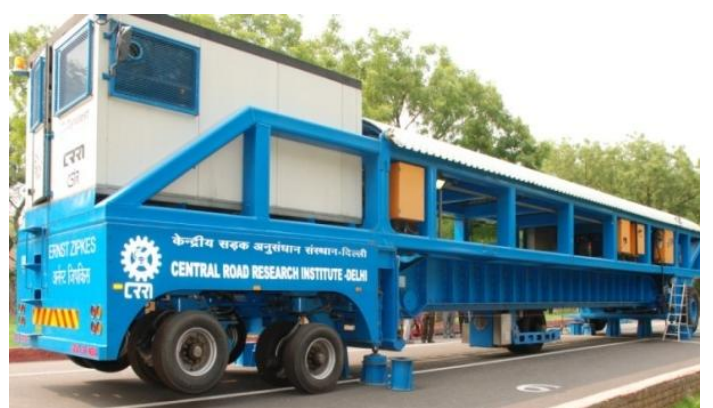

Fig 2: HVS(APTF) Operating at CSIR-CRRI

\begin{tabular}{|l|l|}
\hline \multicolumn{2}{|c|}{ Table 1. Features of HVS Mark IV+ APT } \\
\hline Feature & Capability \\
\hline Mobility & $\begin{array}{l}\text { Towable over long distances; } \\
\text { self-propelled over short } \\
\text { distances }\end{array}$ \\
\hline Load Application & $\begin{array}{l}\text { Static \& Dynamic Load } \\
\text { Applications }\end{array}$ \\
\hline Wheel Loads & $\begin{array}{l}\text { Mean Load }: 36-88 \mathrm{kN} ; \text { Peak } \\
\text { Load }: 30-105.6 \mathrm{kN}\end{array}$ \\
\hline Test Wheel (s) & $\begin{array}{l}\text { Single, Super-single, Dual (truck) } \\
\text { or Aircraft (Airbus } 46 \times 16)\end{array}$ \\
\hline Tyre Pressure & $\begin{array}{l}\text { Typically } 560-690 \mathrm{kPa} \text { on roads } ; \\
\text { Upto } 1450 \mathrm{kPa} \text { on airfields }\end{array}$ \\
\hline Repetitions Per Day & $\begin{array}{l}\text { Upto } 32000 \text { (Bi-directionally) } \\
\text { Upto } 16000 \text { (Uni-directionally) }\end{array}$ \\
\hline Trafficked Length & 8m (test area length 6m) \\
\hline Trafficked Width & $\begin{array}{l}\text { Upto } 1.5 \mathrm{~m} \text {, depending on wheel } \\
\text { configuration }\end{array}$ \\
\hline Trafficking Pattern & Variable \\
\hline Dimensions & $\begin{array}{l}\text { Length }=22.8 \mathrm{~m} ; \text { Width }=3.5 \mathrm{~m} \\
; \text { Height }=4.0 \mathrm{~m}\end{array}$ \\
\hline Total Mass & $\begin{array}{l}\text { Diesel (self contained) or electric } \\
\text { shore power }\end{array}$ \\
\hline Power Source & Ka \\
\hline
\end{tabular}




\subsection{Flexible Pavement Test Strip:}

A flexible pavement test section was designed (2) for a design traffic of 30 million standard axles (msa), with a subgrade CBR of 5\%, layer of granular sub-base (GSB) materials of thickness $300 \mathrm{~mm}$, wet mix macadam (WMM) as base layer of thickness $250 \mathrm{~mm}$ and Dense Bitumen Macadam (DBM) and Dense Bituminous Concrete (DBC) of thicknesses $120 \mathrm{~mm}$ and $40 \mathrm{~mm}$ respectively.

The above mentioned layer construction of the pavement structure was accomplished incorporating the specifications of 'Ministry of Road Transport \&Highways' ( $4^{\text {th }}$ Revision $)$.

The material properties are given in tables 2, 3 and 4 .

Table 2: Aggregate Gradations for DBC \& DBM Mixture

\begin{tabular}{|c|c|c|c|c|}
\hline \multirow{2}{*}{ Sieve Size (mm) } & \multicolumn{2}{|c|}{ DBC } & \multicolumn{2}{c|}{ DBM } \\
\cline { 2 - 5 } & $\begin{array}{c}\text { Cumulative \% } \\
\text { by weight of } \\
\text { total aggregate } \\
\text { passing, }\end{array}$ & $\begin{array}{c}\text { Gradation } \\
\text { obtained }\end{array}$ & $\begin{array}{c}\text { Cumulative \% } \\
\text { by weight of total } \\
\text { aggregate passing }\end{array}$ & $\begin{array}{c}\text { Gradation } \\
\text { obtained }\end{array}$ \\
\hline 75 & 100 & 100.00 & 100 & 100.00 \\
\hline 26.5 & 100 & 100 & $90-100$ & 100.00 \\
\hline 19 & $79-100$ & 90.51 & $71-95$ & 96.08 \\
\hline 13.2 & $59-79$ & 60.50 & $56-80$ & - \\
\hline 9.5 & $52-72$ & 52.45 & - & 49.26 \\
\hline 4.75 & $35-55$ & 37.33 & $38-54$ & 29.96 \\
\hline 2.36 & $28-44$ & 31.50 & $28-42$ & - \\
\hline 1.18 & $20-34$ & 20.15 & - & 9.14 \\
\hline 0.6 & $15-27$ & 17.44 & - & - \\
\hline 0.3 & $10-20$ & 11.74 & - & 2.06 \\
\hline 0.15 & $5-13$ & 7.08 & $2-8$ & \\
\hline 0.075 & $2-8$ & 3.16 & & - \\
\hline
\end{tabular}

Table 3 : Volumetric and Mechanical properties of DBC mix and DBM

\begin{tabular}{|c|c|c|c|c|c|c|c|}
\hline $\begin{array}{c}\text { Binder } \\
\text { type in } \\
\text { mix }\end{array}$ & $\begin{array}{c}\text { Optimum } \\
\text { Binder } \\
\text { Content }(\%)\end{array}$ & $\begin{array}{c}\text { Bulk } \\
\text { Density(g/cc) }\end{array}$ & $\begin{array}{c}\text { Marshall } \\
\text { Stability } \\
(\mathbf{k N})\end{array}$ & $\begin{array}{c}\text { Retained } \\
\text { Marshall } \\
\text { Stability } \\
\mathbf{\%}\end{array}$ & $\begin{array}{c}\text { Flow } \\
(\mathbf{m m})\end{array}$ & $\begin{array}{c}\text { Air } \\
\text { voids } \\
(\%)\end{array}$ & $\begin{array}{c}\text { VFB } \\
(\%)\end{array}$ \\
\hline DBC & 5.1 & 2.280 & 10.22 & 83 & 3.1 & 4.2 & 71.7 \\
\hline DBM & 5.0 & 2.301 & 10.15 & 79 & 3.5 & 4.9 & 69.3 \\
\hline
\end{tabular}

Table 4: Aggregate Gradations for WMM \& GSB Mix

\begin{tabular}{|c|c|c|c|c|}
\hline \multirow[t]{2}{*}{ Sieve Size (mm) } & \multicolumn{2}{|c|}{ Wet Mix Macadam(WMM) } & \multicolumn{2}{|c|}{ Granular Sub-base(GSB) } \\
\hline & $\begin{array}{c}\text { Cumulative \% } \\
\text { by weight of } \\
\text { total aggregate } \\
\text { passing, } \\
\text { Cnocifind Volmoc }\end{array}$ & $\begin{array}{c}\text { Gradation } \\
\text { obtained }\end{array}$ & $\begin{array}{c}\text { Cumulative \% } \\
\text { by weight of total } \\
\text { aggregate passing }\end{array}$ & $\begin{array}{c}\text { Gradation } \\
\text { obtained }\end{array}$ \\
\hline 75.0 & -- & & 100 & 100 \\
\hline 53.0 & 100 & 100 & $80-100$ & 91 \\
\hline 45.0 & $95-100$ & 100 & -- & \\
\hline 26.5 & -- & & $55-90$ & 78 \\
\hline 22.4 & $60-80$ & 66 & - & \\
\hline 11.2 & $40-60$ & 48 & -- & \\
\hline 9.50 & - & & $35-65$ & 58 \\
\hline 4.75 & $25-40$ & 29 & $25-55$ & 49 \\
\hline 2.36 & $15-30$ & 19 & $20-40$ & 37 \\
\hline 0.600 & $8-22$ & 20 & -- & \\
\hline 0.425 & -- & & $10-25$ & 21 \\
\hline 0.075 & $0-8$ & 7 & $3-10$ & 8 \\
\hline $\begin{array}{l}\text { Max. Dry Density(MDD), } \\
\mathrm{g} / \mathrm{cc}\end{array}$ & \multicolumn{2}{|c|}{2.26} & \multicolumn{2}{|c|}{2.19} \\
\hline $\begin{array}{l}\text { Field Dry Density(FDD), } \\
\mathrm{g} / \mathrm{cc}\end{array}$ & \multicolumn{2}{|c|}{2.23} & \multicolumn{2}{|c|}{2.16} \\
\hline CBR at FDD & \multicolumn{2}{|l|}{71} & \multicolumn{2}{|l|}{58} \\
\hline
\end{tabular}




\subsection{Evaluation of Test Section using APT and Data Acquisition:}

A half axle load of $80 \mathrm{kN}$ on dual wheels was applied on the test section having tyre pressure of 700 $\mathrm{kPa}$. Single wheel path, bi-directional traffic was used for load application. The load was applied for 2,75,000 repetition for every 5,000 passes upto 50,000 passes, thereafter at every 10,000 passes upto 175,000 passes and then at every 25,000 passes upto 275,000 passes, adding upto 4.4 msa using AASHTO power law. The average speed was $10 \mathrm{kmph}$ and test period was from Oct. 2011-Dec. 2012 where APTF was operated only during day time. Since, temperature and rutting magnitude along with mix properties are the most significant primary parameters for the study of asphalt failure in the form of rutting, therefore, temperature sensors were embedded at bituminous layers which were used for the measurement of pavement temperature. The details of bituminous mix properties are already detailed before in the tables, but environmental / temperature control measures were not able to be adopted in order to get data nearer to the true life situation.

The continuous changes in profile resulting in rutting were also measured and recorded by portable laser profilometer. Prior to trafficking, cross-sections were marked out at 0.5 -m intervals for $8 \times 1 \mathrm{~m}$ (length $\mathrm{x}$ breadth) test section of the road.

\section{Data Analysis:}

The temperature of pavement was taken at 50mm below the bituminous surface using K-type thermocouple:

Table 5:

\begin{tabular}{|c|c|}
\hline MONTH & Average Monthly Pavement Temperature, ${ }^{0} \mathrm{C}$ \\
\hline OCTOBER & 26.185 \\
\hline NOVEMBER & 20.7375 \\
\hline DECEMBER & 18.1775 \\
\hline
\end{tabular}

As there was little variation in temperature in the evaluation period, so this was taken as constant parameter.

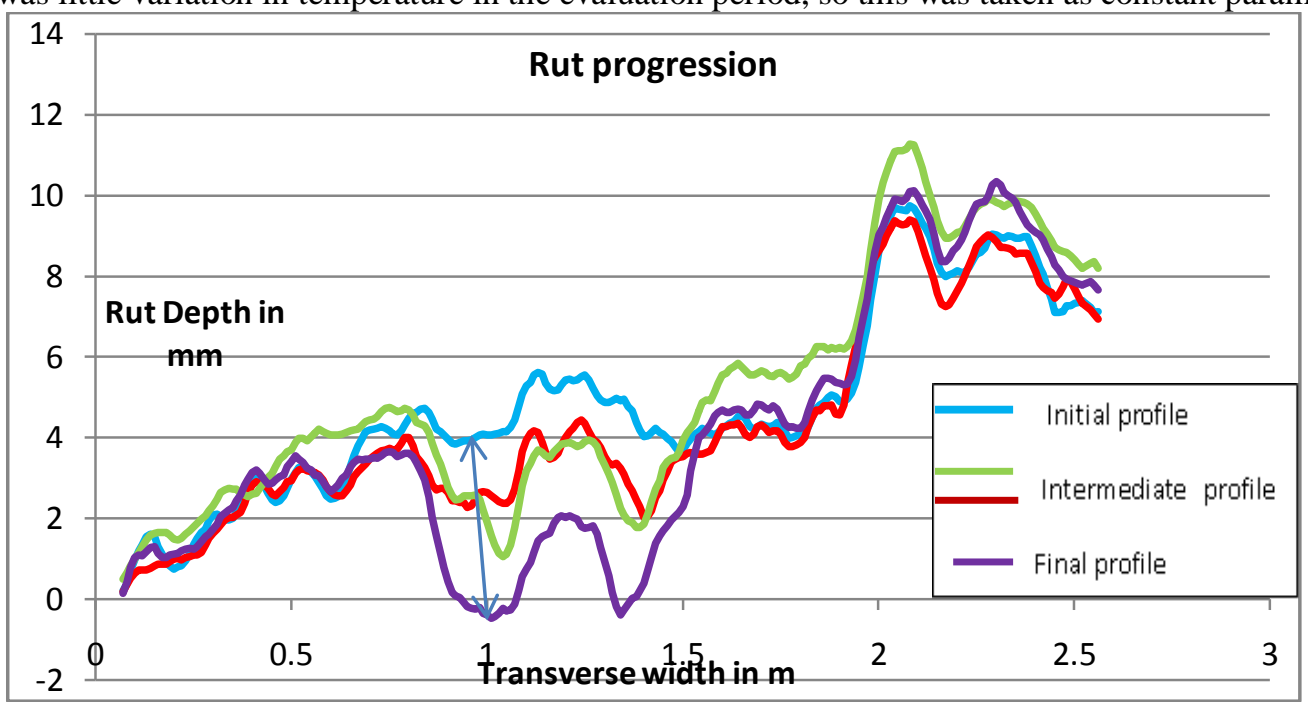

Fig3:Rut progression with number of passes

The rut progression was obtained using moving average of order nine for a smooth curve Correlation were attempted between dependent variable as rut depth and number of repetitions as number of standard repetitions keeping all other variables as constants (figure 3). 


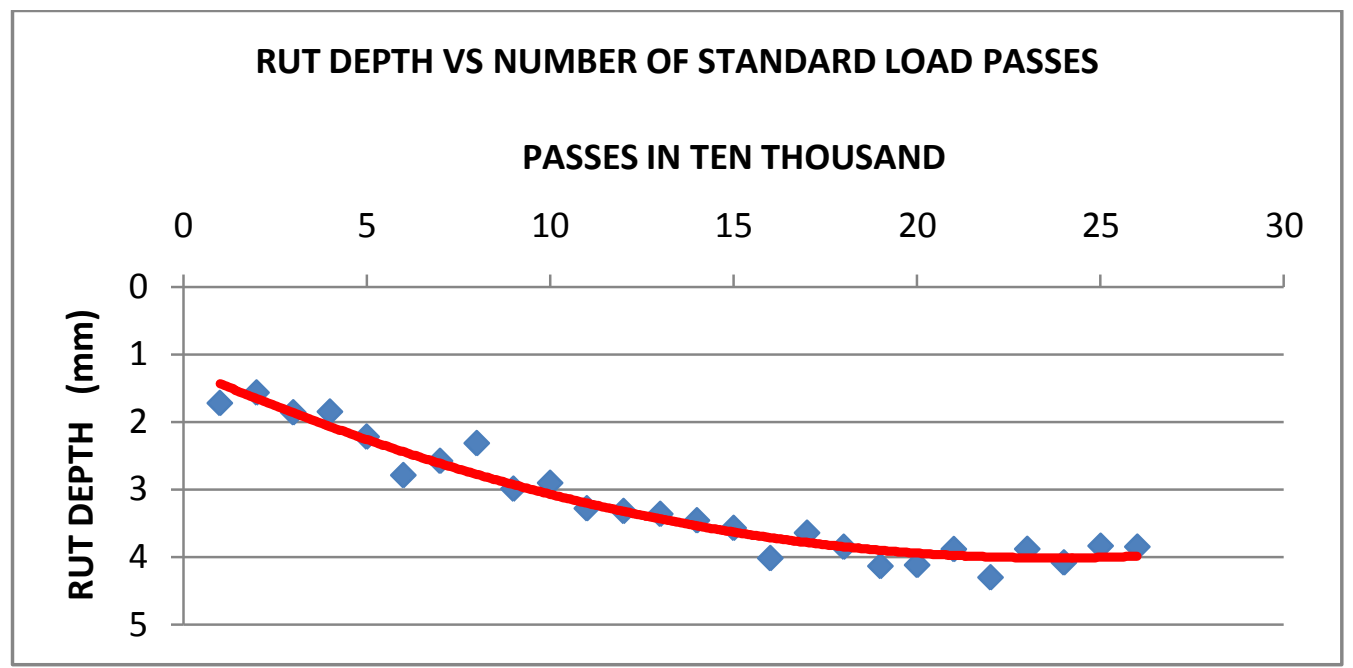

Fig 4: Best Fit Line of the Scatter Points

\section{Conclusions:}

1) Best fit line is obtained from trend line of second degree polynomial and was found to be quite realistic.

2) The best fit line equation for the scatter points of rut depth with number of passes was found out to be $y=-$ $0.005 x^{2}+0.2368 x+1.1988$

3) The value of T-test was found to be significant i.e. 7.3813 and also the coefficient of regression was also found out to be $95 \%$.

4) The rut depth of about $1 \mathrm{~mm}$ is being visible even at the start of load repetitions is due to camber profile, since the measurement were done using laser sensors.

5) The best fit line is almost parallel to $\mathrm{x}$-axis after about 200000 repetitions (3.2 msa)indicating a saturation level after $4 \mathrm{~mm}$ of rut depth.

6) The phenomenon of consolidation / settlement (rutting) in bituminous layers after few repetitions of standard load is quite evident in Figure 2.

7) After $4 \mathrm{~mm}$ of rut depth which is quite minimal, the effect of further number of load repetitions is not visible indicating the phenomenon of initial settlement level of DBC layers.

\section{Acknowledgements:}

The authors are highly thankful to Dr.S.Gangopadhyay, Director, CSIR-CRRI for the encouragement, support and guidance in CSIRCRRI's APTF Program. The inputs of Mr. Abhishek Mittal, Senior Scientist, Flexible Pavement Division, CSIR-CRRI are duly acknowledged. Also, the authors express their thanks for all the member of CSIR-Central Road Research Institute who has helped in this project.

\section{References:}

[1]. Dr. Roque.,Reynaldo, Dr.Birgisson Bjorn, Mr. Darku Daniel, Mr. Christos A.Drakos Evaluation of laboratory testing systems for asphalt mixture design and evaluation, Florida department of Transportation, www.dot.state.fl.us/researchcenter/Completed.../FDOT_BB888.pdf. ,2004

[2]. Guidelines for the Design of Flexible Pavement,Indian Road Congress -37:2001.

[3]. Wang, H., Zhang, Q., and Tan, J. "Investigation of Layer Contributions to Asphalt Pavement Rutting.” J. Mater. Civ. Eng. 21, SPECIAL ISSUE: China: Innovative Use of Materials for Highway Construction,2009

[4]. Hugo, F., B.F. McCullough, and B. Van der Walt, "Full- Scale Accelerated Pavement Testing for the Texas State Department of Highways and Public Transportation," Transportation Research Record 1293, Transportation Research Board, National Research Council, Washington, D.C., 1991. 